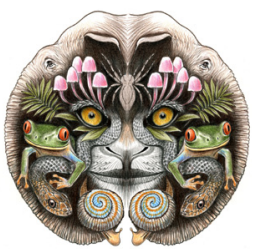

ISSN

Online 0974-7907

Print 0974-7893
The Asian Elephant Elephas maximus Linnaeus, 1758 is listed as an Endangered species (Choudhury et al. 2008). The Sri Lankan sub population of Asian Elephant is also listed as a Nationally Endangered species (MOE 2012). In addition to its wild population, Sri Lanka currently maintains a captive population of elephants for various purposes including exhibition, work and for cultural pageants (Canon \& Davis 1995). Almost all captive elephants in Sri Lanka are caught from the wild at a young age. However, little work has been done to evaluate how different management conditions affect the physiology of captive elephants. Captive animals, including elephants, have shown a tendency towards being stressed (Odgen et al. 1994; Elzanowsky \& Sergiel 2006) and chronic stress has been shown to reflect in the haematology of animals by the reduction of eosinophils circulating in the blood stream as well as lowering of basophil counts (Barret et al. 2010), lowering of total white blood cell (WBC) counts (Sutherland et al. 2006) and increase of blood glucose concentration (Randall et al. 2001). The increase of the ratio of neutrophils to lymphocytes has also been shown to be an indicator of stress (Rossdale et al. 1982; Kock et al. 1999). Therefore we studied the haematology of elephants from three different captive conditions to compare how the management methods affected the haematology of the animals.

Materials and Methods: The study was conducted from July to September 2012. The three study sites chosen were the National Zoological Gardens

\section{A COMPARATIVE HAEMATOLOGICAL ANALYSIS OF ASIAN ELEPHANTS ELEPHAS MAXIMUS LINNAEUS, 1758 (MAMMALIA: PROBOSCIDEA: ELEPHANTIDAE) MANAGED UNDER DIFFERENT CAPTIVE CONDITIONS IN SRI LANKA}

Ruvinda Kasun de $\mathrm{Mel}^{1}$, Devaka Keerthi Weerakoon ${ }^{2}$, Wanigasekara Daya Ratnasooriya ${ }^{3}$ \& Ashoka Dangolla ${ }^{4}$

1,2,3 Department of Zoology, University of Colombo, Colombo 3, Sri Lanka

${ }^{4}$ Department of Veterinary Clinical Sciences, University of Peradeniya, Peradeniya, Sri Lanka

${ }^{1}$ ruvinda_demel@hotmail.com (corresponding author), ${ }^{2}$ devakaw@ gmail.com, ${ }^{3}$ wdr@zoology.cmb.ac.lk, ${ }^{4}$ adangolla@gmail.com

(6 $6^{0} 51^{\prime 2} 25.51^{\prime \prime} N$ \& 79052'25.62"E) (NZG), the Pinnawala Elephant Orphanage $\left(7^{0} 18^{\prime} 7.19^{\prime \prime} \mathrm{N} \& 80^{\circ} 23^{\prime} 13.60^{\prime \prime} \mathrm{E}\right)$ (PEO) and the Millennium Elephant Foundation ( $\left.7^{\circ} 16^{\prime} 24.58^{\prime \prime} \mathrm{N} \& 80^{\circ} 23^{\prime} 1.20^{\prime \prime} \mathrm{E}\right)$ (MEF). The NZG animals live a highly sedentary life as they are chained for the most part of the day and intra specific behaviour is limited. The PEO animals are allowed to engage in intra specific behaviours and are taken for baths in the 'Maoya' river one kilometer away. The animals at MEF are used for elephant rides throughout the day within the MEF premises and thus have an opportunity for intra specific behaviours as well as exercise.

Four adult females were sampled at NZG while only two animals each could be sampled from PEO and MEF (two adult males and two adult females) due to logistical constraints. All animals were sampled on four consecutive days between 0800-0900 hr. In order

\footnotetext{
DOI: http://dx.doi.org/10.11609/JoTT.o3761.6148-50
}

Editor: Ulrike Streicher, Wildlife Veterinarian / Wildlife Management Consultant, Danang, Vietnam.

Date of publication: 26 July 2014 (online \& print)

Manuscript details: Ms \# 03761 | Received 07 September 2013 | Final received 11 July 2014 | Finally accepted 13 July 2014

Citation: de Mel, R.K., D.K. Weerakoon, W.D. Ratnasooriya \& A. Dangolla (2014). A comparative haematological analysis of Asian Elephants Elephas maximus Linnaeus, 1758 (Mammalia: Proboscidea: Elephantidae) managed under different captive conditions in Sri Lanka. Journal of Threatened Taxa 6(8): 6148-6150; http://dx.doi.org/10.11609/JoTT.03761.6148-50

Copyright: (c) de Mel et al. 2014. Creative Commons Attribution 4.0 International License. JoTT allows unrestricted use of this article in any medium, reproduction and distribution by providing adequate credit to the authors and the source of publication.

Funding: None.

Competing Interest: The authors declare no competing interests.
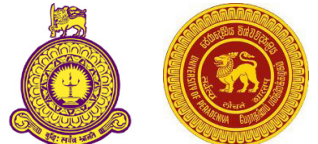

Acknowledgements: The authors wish to thank Ms. Dhammika Malsinghe (Asst. Director National Zoological Gardens), Dr. Nirmalie Pallewatte (Head, Dept. of Zoology, Faculty of Science, University of Colombo), Mr. H. Jayakody (Dept. of Zoology, Faculty of Science, University of Colombo), Dr. D.K. Nanayakkara (Dept. of Nuclear Medicine, Faculty of Medicine, University of Peradeniya) , Dr. Jagath Jayasekera (Vet. Surgeon, National Zoological Gardens), Dr. C. Rajapakse (Vet. Surgeon, Pinnawala Elephant Orphanage) 
to draw blood, the elephants were ordered to assume a lateral recumbancy position by the mahout. Then, $5 \mathrm{ml}$ of blood was drawn from an ear vein on the posterior surface of the ear by a qualified veterinary surgeon using an 18 gauge sterile hypodermic needle (Sumbow medical instruments, Ningbo, China) and a $10 \mathrm{ml}$ disposable syringe (Changzhou medical appliances, Jiangsu province, China). This method has been used by Ratnasooriya et al. (1995). The collected blood was then transferred into an EDTA coated tube (APTACA Canelli-Italy) and gently turned upside-down 2-3 times to ensure the blood wouldn't clot. Blood smears were prepared to be used in the differential counts which were performed under an oil immersion microscope (Model cx21FS2, Olympus Corporation, Tokyo, Japan), while white blood cells (WBC) and red blood cell (RBC) were counted using an improved neubauer double cell hemocytometer (Hawksley \& Sons Ltd, Sussex, England) following previously established procedures (Dacie \& Lewis 1997). Packed Cell Volume (PCV) was determined using a Hematocrit centrifuge (Hawksley, England). The values of PCV and RBC counts were used to compute the mean corpuscular volumes (MCV).

Minitab version 15 was used to analyse the results statistically. The Kruskal-Wallis test at a 95\% confidence interval followed by a post-hoc test of a pair wise comparison using Mann-Whitney $U$ test at a 95\% confidence interval was conducted to determine differences between groups.

Ethical clearance for the project was obtained from the Institute of Biology Sri Lanka (Registration number: ERCIOB101/05/12) while permission from the Department of National Zoological Gardens was obtained to use their animals in the research project.

Results: Table 1 shows the results for the various haematological parameters.

The glucose levels of the elephants kept at MEF were significantly higher than the glucose levels of the animals kept at NZG and PEO (Kruskal-Waalis, $\mathrm{H}=6.88$, 2d.f., $P=0.032$,). The total WBC counts of elephants kept at NZG were shown to be significantly lower than WBC counts of elephants kept at PEO and MEF $v$ (KruskalWallis, $\mathrm{H}=21.92$, 2d.f., $\mathrm{P}=0.000$ ). The lymphocyte counts of the animals kept at NZG were significantly lower compared to those of the animals kept at PEO and MEF (Kruskal-Wallis, $\mathrm{H}=16.40,2$ d.f., $\mathrm{P}=0.00$ ). The percentages of monocytes differed significantly between the three groups (Kruskal-Wallis, $\mathrm{H}=16.73,2$ d.f., $\mathrm{P}=0.000$ ) with the animals kept at NZG showing the highest values while the animals kept at MEF had the lowest values. The PCV differed significantly and were higher in the elephants kept at NZG and PEO than in the elephants kept at MEF. The ratio of neutrophils to lymphocytes were again shown to be significantly different (KruskalWallis, $\mathrm{H}=14.58,2$ d.f., $\mathrm{P}<0.05)$ with the NZG value being highest. No other haematological parameter showed a significant difference between the three groups (KruskalWallis, $\mathrm{P}>0.05$ ).

Discussion: All values of the haematological parameters found in our study fall within the ranges previously reported for captive Asian Elephants (Ratnasooriya et al. 1990; Yathiraj et al. 1992). However, the total WBC counts and lymphocyte counts were significantly lower while the ratio of neutrophils to lymphocytes was significantly higher in the elephants from NZG. Decreases of lymphocytes have been seen previously in animals under stress due to confinement and sleep deprivation (Ferrante et al. 1998; Pottinger \& Pickering 1992; Zager et al. 2007) and similar decreases of WBC have been seen in animals which were stressed due to overcrowding and heat (Sutherland et al. 2006). Elevated ratios of neutrophils to lymphocytes have also been observed in stressed animals such as horses (Rossdale et al. 1982), rhinos (Kock et al. 1999) and rhesus monkeys (Morrow-Tesch et al. 1993). The significantly elevated glucose levels of the animals kept at MEF could be due to the fact that they receive food material rich in glucose (fruits, sugar cane) between

Table 1. Means \pm SDs of Haematological parameters of the three study groups. ( ${ }^{*}$ Indicates significantly different parameters)

\begin{tabular}{|c|c|c|c|c|c|c|c|c|c|c|c|}
\hline Site & $\begin{array}{l}\text { WBC }\left(10^{3} /\right. \\
\mu l) \\
\text { Mean } \pm S D *\end{array}$ & $\begin{array}{l}\text { RBC }\left(10^{6} /\right. \\
\mu l) \\
\text { Mean } \pm S D\end{array}$ & $\begin{array}{l}\text { Neutrophils } \\
\% \\
\text { Mean } \pm \text { SD }\end{array}$ & $\begin{array}{l}\text { Eosinophils } \\
\% \\
\text { Mean } \pm \text { SD }\end{array}$ & $\begin{array}{l}\text { Basophils \% } \\
\text { Mean } \pm S D\end{array}$ & $\begin{array}{l}\text { Lymphocytes } \\
\% \\
\text { Mean士SD * }\end{array}$ & $\begin{array}{l}\text { Monocytes } \\
\% \\
\text { Mean } \pm S D *\end{array}$ & $\begin{array}{l}\text { Blood } \\
\text { glucose } \\
\text { (mmol/I) } \\
\text { Mean } \pm S D *\end{array}$ & $\begin{array}{l}\text { PCV \% } \\
\text { Mean } \pm S D *\end{array}$ & $\begin{array}{l}\text { MCV (fl) } \\
\text { Mean } \pm S D\end{array}$ & $\begin{array}{l}\text { Neut: } \\
\text { Lypmh } \\
\text { Mean } \pm \text { SD } \\
*\end{array}$ \\
\hline NZG & $5.02 \pm 0.32$ & $3.42 \pm 0.32$ & $49.05 \pm 3.16$ & $5.34 \pm 2.03$ & $1.56 \pm 0.98$ & $40.05 \pm 1.95$ & $3.32 \pm 1.17$ & $4.7 \pm 0.51$ & $36.63 \pm 5.65$ & $107.4 \pm 16.07$ & $1.22 \pm 0.12$ \\
\hline PEO & $8.17 \pm 0.77$ & $3.87 \pm 0.58$ & $44.5 \pm 6.30$ & $4.11 \pm 2.98$ & $1.6 \pm 1.40$ & $46.51 \pm 6.59$ & $2.38 \pm 1.17$ & $4.61 \pm 0.35$ & $36.12 \pm 1.81$ & $94.81 \pm 13.06$ & $0.99 \pm 0.29$ \\
\hline MEF & $7.76 \pm 0.66$ & $3.21 \pm 0.44$ & $40.51 \pm 1.19$ & $3.46 \pm 0.52$ & $1.1 \pm 0.29$ & $53.3 \pm 1.46$ & $0.79 \pm 0.47$ & $5.37 \pm 0.63$ & $28.83 \pm 4.07$ & $1.13 \pm 7.90$ & $0.76 \pm 0.03$ \\
\hline
\end{tabular}


the walks. This would elevate the blood glucose levels, which would be reflected in the tests. The reason for the significantly lower monocyte counts found in elephants kept at MEF and PEO in comparison to the counts found in animals from NZG remains at the moment unknown. The significantly reduced PCV values of the elephants from MEF compared to the elephants from NZG and PEO could be due to the fact that the elephants kept at MEF have more opportunities to keep themselves hydrated. Dehydration has been shown to be a promoting factor of high PCV values (Maloiy \& Boarer 1971). The elephants from MEF during their many walks come regularly to the waterway and this provides them with ample opportunity to drink and sprinkle water on their bodies. This may be important for elephants as they are poor thermoregulators (Weissenbock et al. 2012). Dehydration in the elephants kept at NZG could thus be a result of comparatively limited access to water and also be a factor that promotes a certain amount of chronic stress. Due to logistical reasons the sample size in this study is small and prevents us from drawing conclusive remarks with confidence. However, based on the haematological parameters assessed in this study, we conclude that the elephants at NZG are under slightly higher levels of stress compared to the elephants at PEO and MEF. The assessment of Cortisol hormone (de Mel et al. 2013a) and the assessment of stereotypic behaviour (de Mel et al. 2013b) done using these same animals simultaneously to this study indicates that the NZG animals were at a higher level of chronic stress comparatively. However, all elephants were apparently healthy and therefore stress may not have affected them to a significant level. Obviously more thorough and comprehensive studies must be conducted and other parameters to assess stress must be included before definite conclusions can be drawn.

\section{References}

Barret, K.E., S.M. Barman, S. Boitano \& H.L. Brooks (eds.) (2010) Ganong's Review of Medical Physiology - 23 $3^{\text {rd }}$ Edition. McGraw-Hill Medical, 726pp

Canon, P. \& P. Davis (1995). ALIYA; Stories of the Elephants of Sri Lanka. Airavata Press. Melbourne, 102pp.

Choudhury, A., D.K.L. Choudhury, A. Desai, J.W. Duckworth, P.S. Easa, A.J.T. Johnsingh, P. Fernando, S. Hedges, M. Gunawardena, F. Kurt, U. Karanth, A. Lister, V. Menon, H. Riddle, A. Rübel \& E. Wikramanayake (IUCN SSC Asian Elephant Specialist Group) (2008). Elephas maximus. The IUCN Red List of Threatened Species. Version 2014.1. <www.iucnredlist.org>. Downloaded on 16 July 2014.

de Mel, R.K., M.R.D. Kumara, A. Dangolla, J. Jayasekera, D.K.K. Nanayakkara, C. Rajapakse, W.D. Ratnasooriya \& D.K. Weerakoon (2013a). An assessment of the stress levels of captive elephants held under different management conditions using serum cortisol levels. Book of Abstracts Peradeniya University Research Sessions. 17: 215.

de Mel, R.K., D.K. Weerakoon \& W.D. Ratnasooriya (2013b). A comparison of Stereotypic Behaviour in Asian Elephants at Three Different Institutions in Sri Lanka. Gajah 38: 25-29.

Dacie, J.V. \& S.M. Lewis (1991). Practical Haematalogy. Longman Singapore Publishers. Singapore, 41-55pp.

Elzanowski, A. \& A. Sergiel (2006). Stereotypic behavoiur of a female Asiatic Elephant (Elephas maximus) in a zoo. Journal of Applied Animal Welfare Science 9: 223-232; http://www.dx.doi. org/10.1207/s15327604jaws0903_4

Ferrante, V., E. Canali, S. Mattiello, M. Verga, P. Sacerdote, B. Manfredi \& A.E. Panerai (1998). Preliminary study on the effect of size of individual stall on the behavioural and immune reactions of dairy calves. Journal of Animal Feed Science 7(1): 29-36.

Kock, R.A., S.R.O. Mihok, J. Wambua, J. Mwanzia \& K. Saigawa (1999). Effects of translocation on hematologic parameters of free-ranging Black Rhinoceros (Diceros bicornis michaeli) in Kenya. Journal of Zoo and Wildlife Medicine 30: 389-396.

Maloiy, G.M.O. \& C.D.H. Boarer (1971). Response of the Somali donkey to dehydration: hematological changes. American Journal of Physiology 221(1): 37-41.

MOE (2012). The Taxonomy and Conservation Status of Mammals in Sri Lanka, pp. 134-144. In: Weerakoon, D.K. \& S. Wijesundara (eds.). The National Red List 2012 of Sri Lanka; Conservation Status of the Fauna and Flora. Ministry of Environment, Colombo, Sri Lanka.

Morrow-Tesch, J.L., J.J. McGlone \& R.L. Norman (1993). Consequences of restraint stress on natural killer cell activity, behavior, and hormone levels in Rhesus Macaques (Macaca mulatta). Psychoneuroendocrinology 18: 383- 395.

Ogden, J.J., D.G. Lindburg \& T.L. Maple (1994). A preliminary study of the effects of ecologically relevant sounds on the behaviour of captive Lowland Gorillas. Applied Animal Behavouir Science (39): 163-176

Pottinger, T.G. \& A.D. Pickering (1992). The influence of social interaction on the acclimation of Rainbow Trout, Oncorhynchus mykiss (Walbaum) to chronic stress. Journal of Fish Biology 41(3): 435-447.

Randall, D., W. Burggren \& K. French (2001). Animal Physiology - $5^{\text {th }}$ Edition. W.H. Freeman and Company, New York, 338-339pp.

Ratnasooriya, W.D., A.B.C. Amarasinghe \& D.S. Kodikara (1995). Total serum cholesterol levels of Sri Lankan Elephants (Elephas maximus maximus). Ceylon Journal of Science 24(1): 11-16.

Ratnasooriya, W.D., S.B.U. Fernando, A.M.V.R. Manatunga, H.S. Caldera, G.K. Liyanage \& G.A.S. Premakumara (1990). Haematological values for adult Asian Elephants (Elephas maximus maximus) at the Pinnawala Elephant Orphanage, Sri Lanka. Medical Science Research 18: 899-902.

Rossdale, P.D., P.N. Burguez \& R.S.G. Cash (1982). Changes in blood neutrophil/lymphocyte ratio related to adrenocortical function in the horse. Equine Veterinary Journal 14: 293-298.

Sutherland, M.A., S.R. Niekamp, S.L. Rodriguez-Zas \& J.L. SalakJohnson (2006). Impacts of chronic stress and social status on various physiological and performance measures in pigs of different breeds. Journal of Animal Science 84(3): 588-596

Weissenbock, N.M., W. Arnold \& W. Ruf (2012). Taking the heat: thermoregulation in Asian Elephants under different climatic conditions. Journal of Comparative Physiology B 182(2): 311-319.

Yathiraj, S., P.C. Choudhuri, D.S.T Rao \& P.K. Reddy (1992). Clinicohaematological observations on Indian Elephant (Elephas maximus indicus). Indian Veterinary Journal 69: 995-997.

Zager, A., M.L. Anderson, F.S. Ruiz, I.B. Antunes \& S. Tufik (2007). Effects of acute and chronic sleep loss on immune modulation of rats. American Journal of Phsiology-Regulatory Integrative and Comparative Physiology 293(1): 504-509.

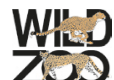

